\title{
Reflecting on new developmentalism and classical developmentalism
}

\author{
Luiz Carlos Bresser-Pereira* \\ Professor Emeritus, Getúlio Vargas Foundation, São Paulo, Brazil
}

This paper, first, distinguishes new developmentalism (a new theoretical system that is being created) from 'really existing' developmentalism (a form of organizing capitalism). Second, it distinguishes new developmentalism from its antecedents, development economics or classical developmentalism and Keynesian macroeconomics. Third, it discusses the false opposition that some economists have adopted between new developmentalism and social-developmentalism, which the author understands as a form of really existing developmentalism; as theory, it is just a version of classical developmentalism with a bias toward immediate consumption. Finally, it makes a summary of new developmentalism of its main political economy, economic theory, and economic policy claims.

Keywords: developmentalism, social-developmentalism, developmental macroeconomics

JEL codes: $B 20, O 59, E 10$

\section{INTRODUCTION}

What is new developmentalism and how is it distinguished from classical developmentalism that preceded it? ${ }^{1}$ Following the publication of my book Developmental Macroeconomics (2014), coauthored with José Luis Oreiro and Nelson Marconi, where we systematize the ideas and models that a group of economists have been developing on the economic theory of new developmentalism since the early 2000s, I realized that it was important to reflect on the real meaning of the term. Since I introduced the new developmentalism concept in 2003, some, including myself, understood it not only as a theory but also as a form of economic and political organization of capitalism, which was a mistake. It is important to distinguish new developmentalism as well as the preceding classical developmentalism from developmentalism as a 'really existing' historical phenomenon - as a form of state and of capitalism, which serves as an alternative to economic liberalism. It is time to see how much it

* Email: bressepereira@gmail.com; www.bresserpereira.org.br. I am grateful to Marcus Ianoni, Luiz Fernando de Paula, Nelson Marconi, Philippe Faucher, and Marco Capraro Brancher for their valuable comments.

1. By classical developmentalism I mean 'development economics' or 'structuralist development theory,' which was mainstream between the 1940s and the 1960s. I originally used old developmentalism, but the expression seemed pejorative. On the other hand, 'development economics' is a denomination too broad, and 'structuralist development theory' is only recognized in Latin America. I owe to Ricardo Bielschowsky the expression 'classical developmentalism.' 
is critical of its direct antecedent, classical developmentalism, which was part of the mainstream between the 1940s and the 1960s. Really existing developmentalism is a historical occurrence; it is a form of political and economic organization of capitalism, whereas classical and new developmentalism are economic and political theories aiming to explain progress or human development.

The history of capitalism is also the history of really existing developmentalism (Bresser-Pereira 2015). Mercantilism, characterized by the association of the monarchy with the bourgeoisie working to build a large and secure domestic market and to industrialize, was the first historical form of developmentalism. It was a successful one: England, France and Belgium industrialized during mercantilism; all rich countries that realized their industrial revolutions immediately after these three countries, beginning with the United States and principally Germany, adopted a developmental strategy; the developmental state in Asia as well as national-developmentalism in Latin America are in this same category, but these countries had to confront the industrial imperialism of those who got there first. The second developmentalism in the rich countries was the New Deal and Fordism in the United States followed by the Golden Years of Capitalism in Europe after World War II. In Brazil, since the election of a left-wing president, Luis Inácio Lula da Silva, in 2002, there was an attempt to re-establish developmentalism; senator Aloizio Mercadante (2010) called this attempt 'social-developmentalism.' The title seemed good to me, because initially the government was able to reduce inequality and increase the rate of growth, but eventually it proved inadequate because besides the growth rate having returned to the low level of the preceding administration, the attempt to form a developmental class coalition had failed.

New developmentalism is historical-deductive theory based on the successful experiences of fast growth, particularly the recent experience of East Asian countries. As an existing form of capitalism, developmentalism may be authoritarian or democratic, conservative or progressive, and successful or unsuccessful. As a theory, new developmentalism is either right or wrong. As it adopts a historical and holistic approach, the social and political aspects are an essential component of the theory. It seeks to explain how countries, which are late to the industrial and capitalist revolution, experience economic development and increase the material well-being of their population, as well as why many countries fail to achieve progress or human development, that is to say the gradual achievement of political objectives defined by modern societies: national autonomy, social order, economic growth, individual freedom, social justice, and protection of the environment.

All my life I have been trying to understand and make a contribution to this eighteenth-century idea of progress transformed into human development in the twentieth and twenty-first centuries. Borrowing the historical materialism from Marx and Engels, learning from Max Weber, Keynes, and Kalecki, and from classical developmentalism, I have been integrating economics and social and political theory. After a long journey, I came to call this integration new developmentalism. As I understand it now, within new developmentalism there is (a) a method, (b) a political economy, (c) a microeconomics, (d) a macroeconomics, (e) a distributive policy, and (f) an applied economics. The method is the historical-deductive method, not the neoclassical hypothetic-deductive method; the political economy of new developmentalism includes themes like the claim that the origin of economic development was the industrial revolution, the claim that capitalism and the modern state were originally developmental because mercantilist, and the concepts of developmental class coalition and developmental state; the economic theory of new developmentalism 
comprises a developmental macroeconomics already reasonably defined, ${ }^{2}$ and a developmental microeconomics, which, for the moment, is just a draft, but adopts a key distinction between the competitive and the non-competitive sector of modern capitalist economies; the distributive policy is critical of fiscal and exchange rate populism, defending progressive taxes, minimum wage policy, low level for the interest rate and increase of social expenditures or collective consumption; and the applied economics is formed of all papers that empirically substantiate the main claims of new developmentalism.

In Section 2 of this paper, I will offer short information on the branches of new developmentalism; in Section 3, I briefly distinguish new developmentalism from classical developmentalism and from Keynesian macroeconomics; in Section 4, I criticize a proposed alternative to new developmentalism - social developmentalism - and argue that it is a false theoretical alternative, in so far as it does not present alternative models, and a risky policy alternative because it is associated with economic populism and recurrent crises; in Section 5, I summarize new developmentalism; and finally, in Section 6, I conclude that the new developmental macroeconomics requires keeping 'right' the five macroeconomic prices, which entails, besides fiscal and monetary policies, an active exchange-rate policy.

\section{POLITICAL ECONOMY, MICRO AND MACRO}

New developmentalism is oriented to the understanding of middle-income countries, but is also helpful for understanding pre-industrial countries, and, in certain cases (such as the Euro crisis) may inspire rich countries. The political economy of new developmentalism distinguishes productive capitalists, who strive for profits and expansion, from rentier capitalists and financiers, who are remunerated by capitalist rents, that is, interests, rents on real estate, dividends, and capital gains. This political economy has four principal characteristics: first, it views the history of mankind and the history of each country as being divided by the industrial or capitalist revolution; second, it recognizes the relatively dependent character of national bourgeoisies (which are ambiguous or 'national-dependent'), but is critical of dependency theory which incorrectly asserts that a bourgeois revolution is impossible in developing countries; third, it believes that to be successful this capitalist revolution requires the formation of a developmental class coalition associating business entrepreneurs, workers and the public bureaucracy, and identifies an opposing class coalition as the neoliberal one, formed of rentier capitalists, the financiers who manage the wealth of the rentier, and the domestic representatives of the rich countries; and, fourth, proposes that the nation invests in the construction of a capable state, which is developmental and republican, but not necessarily social. A capable state is defined as being endowed with political legitimacy, competent administration, and the ability to finance major investments domestically. A developmental state is defined as being the key instrument to economic growth, coordinating the non-competitive sector of the economy and practicing an active macroeconomic policy - particularly an exchange-rate policy. And it is defined as republican, in that it is strong enough to protect the public

2. Originally I called 'structuralist development macroeconomics' what I am now calling developmental macroeconomics, but because our Routledge editor argued that structuralism is an expression that economists outside Latin America have difficulty in understanding, we arrived at this more direct name. 
patrimony from the rent-seeking of individuals and groups. Historically, as we will see, the first forms of the developmental state are not social or progressive, but conservative; not democratic, but authoritarian. As I argued elsewhere, capitalism tends to become progressive only after becoming democratic. ${ }^{3}$

In so far as the political economy of new developmentalism involves a social theory, it has at its core the concept of 'capitalist revolution,' which was first achieved by England and is the major rupture that a people must experience to develop. The history of each people changes dramatically when it is able to transform itself into a nation, form an autonomous nation-state and realize its industrial revolution, thus bringing to a close the capitalist revolution. Another key concept is the concept of the developmental state and its main role in each capitalist revolution. After that the country will grow faster and with reasonable financial stability if it continues to follow competent developmental policies. Examples include the fast-growing Asian countries. Alternatively, it will fall into recurrent balance-of-payment crises if it either adopts irresponsible developmental policies (usually, abusive expansionary policies) or submits to the neoliberal or Washington-consensus policies and decides to grow with current-account deficits ('foreign savings'), that is, with high current-account deficits.

In relation to political theory, what is the nature of the modern state according to new developmentalism? In rich countries it began as absolutist, changed into the liberal state, then changed again into liberal democracy as people acquired the right to universal suffrage. A little later, with the pressure of the people for less inequality, it changed yet again, this time into a social-democratic state. In this process, the state, particularly in Western Europe, ceased to be, in the words of Marx and Engels in The Communist Manifesto, 'the executive committee of the bourgeoisie.' It became the social-democratic state, where the poor and the middle classes hold some power and participate modestly from the economic surplus. The challenge is to turn this social-democratic state into a republican state, able to defend itself (namely the public patrimony) from the greed of powerful individuals involved in all kinds of lobbying if not outright corruption. In the developing countries, these stages of political development overlap, but a consolidated democracy is achieved only after each country completes its capitalist revolution. Today all countries are pressed to become democratic, but, as I argued in my paper on democracy and the capitalist revolution (Bresser-Pereira 2012), no country was able to make its capitalist revolution in the context of a pre-existing democracy. They formed their nation-state and industrialized, whereas the political regime was either politically liberal (as in the United States) or forthrightly authoritarian (as in most other cases).

Turning to the microeconomics of new developmentalism, it starts from the assumption that the market is an excellent institution for the coordination of economic systems, provided there is competition. Thus, the role of the market and the role of the state in economic coordination depend on the level of actual competition. While neoclassical economics assumes generalized competition as the default condition, new developmentalism distinguishes two sectors in modern capitalist societies - the competitive and the non-competitive sectors - and accordingly, while neoclassical economics believes that economic coordination should be market coordinated, new developmentalism leaves the competitive sector to be market coordinated, and

3. In the paper, 'Democracy and capitalist revolution' (Bresser-Pereira 2012), I argue that democracy only gets consolidated in a country after it formed its nation-state and had its industrial revolution, or, in other words, completed its capitalist revolution. From this moment on, an opportunity is open for the socioeconomic system to become progressive or social-democratic. 
understands that the non-competitive sector, which eventually includes the big banks that are too big to fail, requires planning and day-to-day regulation.

Regarding the macroeconomics, the assumption of developmental macroeconomics is that in developing countries markets are definitely unable to prevent financial crises and are not able to ensure access to foreign and domestic demand. Besides the wellknown market failures that economic theory competently discusses, there is a major market failure - the Dutch disease - which makes the exchange rate overvalued in the long-term, not just in the commodity booms (as the 1982 paper by Corden and Neary proposed). This fact plus three habitual policies - the growth with currentaccount deficits ('foreign savings') policy, a monetary policy around a high-level basic interest rate, and the use of the exchange rate as an anchor to control inflation are the cause of the tendency toward the cyclical and chronic overvaluation of the exchange rate. This long-term overvaluation represents a major obstacle to the industrialization or the productive sophistication of most developing countries. Besides disconnecting the business enterprises that use state-of-the-art technology from domestic as well as foreign demand, the cyclical character of this tendency means that the country will go from currency crisis to currency crisis if it does not pursue an active exchange-rate policy to neutralize it. ${ }^{4}$

Developmental macroeconomics is distinct from classical developmentalism and Keynesian macroeconomics in a few significant areas: (i) the fundamental variables it uses are not the public deficit and the interest rate, but the current-account deficit and the exchange rate; (ii) what distinguishes developing economies from rich economies is no longer a social duality and a poorly structured market, but the fact that the former become indebted in foreign currency and are subject to balance-of-payment crises, whereas the latter become indebted in their own currency and are subject only to banking crises; (iii) contrarily to Keynesian macroeconomics, the existence of demand does not ensure investment and full employment, it is additionally required that the exchange rate assures access to demand, something that is not ensured due to the fact that the exchange rate may be overvalued in the long term; ${ }^{5}$ (iv) contrarily to what one assumes in classical developmentalism, developing countries don't need the capital of rich countries, in so far as (a) when they neutralize the Dutch disease, they will necessarily present a current-account surplus, and (b) foreign savings usually don't add to domestic savings and increase investment, but, rather, increase consumption.

Finally, according to new developmentalism, a lax concept of insufficiency of demand leading to the adoption of expansive fiscal policies 'to distribute income' and the accommodation to an overvalued currency to avoid reduction of real wages are two major mistakes; they are an expression of vulgar Keynesianism or populist developmentalism. Large budget deficits are only required when the insufficiency of demand is causing recession, and they don't reduce economic inequality. As to the exchange rate, when a country depreciates its currency, not only wages but also all the other revenues (interests, rents, and dividends) fall in real terms. Only profits in the tradable industries increase, but this is the objective of the depreciation - to

4. I have written three books on developmental macroeconomics: two theoretical, Globalization and Competition (2010) and Developmental Macroeconomics with José Luis Oreiro and Nelson Marconi (2014), and one applied to Brazil: Developing Brazil (2009b). My papers and books on the matter are assembled at http://bit.ly/1BLscrr and http://bit.ly/1BPU661.

5. On the access to demand problem, see my paper in Jan Kregel's festschrift, Bresser-Pereira (2014). 
make the industrial business enterprises, whose profits are being depressed by the long-term overvaluation, profitable again and ready to invest. Given that the profits of the exporters of commodities are already satisfactory with the old exchange rate, a tax on their exports is required to neutralize the Dutch disease and keep their rate of return under control. This tax is just one of the legitimate instruments that new developmentalism proposes to reduce inequality. The others are: a progressive tax policy; a minimum wage policy; the central bank making its monetary policy around a low (international) interest rate level; and, finally, the expansion of the tax burden to finance increasing social expenditures or collective consumption.

\section{CLASSICAL DEVELOPMENTALISM}

The direct antecedent to new developmentalism is classical developmentalism, which was a response to the failure of markets to coordinate capitalism and to new hopes rising out of the end of World War II. It spanned an era from the mid 1940s into the 1960s. It was a school of thought combining Keynesian macroeconomics with classical political economy, which outstanding economists like Gunnar Myrdal, Arthur Lewis, Paul Rosenstein-Rodan, Ragnar Nurkse, Raul Prebisch, Hans Singer, Celso Furtado, and Albert Hirschman defined. It adopted a historical-deductive method instead of a hypothetical-deductive one, and was critical of neoclassical economics and of the classical law of comparative advantages. In synthesis, it defined industrialization as the main way to achieve economic development, the foreign constraint as a main obstacle to it, and asked for foreign savings; it drafted a concept of economic development as structural change; it argued for an active role for the state; and, in the political realm, it emphasized the role of a developmental class coalition bringing together business industrialists, workers, and the public bureaucracy to build the nation-state and realize the industrial and capitalist revolution.

The World Bank was established according to these principles. The three main economic ideas were industrialization, foreign finance, and a leading role for the state; economic planning had a central role; and the main ideology was economic nationalism or developmentalism. The main political change proposed was the capitalist or bourgeois revolution led by industrial entrepreneurs associated with the public bureaucracy and the workers; the political adversaries were the old oligarchy that exported commodities, the commercial and financial activities involved in foreign trade, and the rich countries - all interested in keeping the country as just an exporter of commodities.

Yet, in the late 1960s, classical developmentalism came under the attack of the associated dependency interpretation, and in the late 1970s, under the attack of monetarism, or, in more general terms, of neoclassical economics, which was at that time recovering the academic hegemony that it had lost to Keynesian thought in the 1930s. Associated dependency started from the assumption that a national bourgeoisie in developing countries was not feasible, because the local bourgeoisies would be essentially dependent, and concluded that instead of trying to achieve national autonomy and realize the capitalist revolution, the best alternative was to become associated with rich countries and grow under their shadow or protection. On the other hand, in the 1970s, an economic crisis put an end to the Golden Years of capitalism and opened the door to neoclassical economics, including the 'new-Keynesian,' which became mainstream in the main universities once again. In the United States and Britain the neoliberal ideology became hegemonic, along with the associated economic liberalization and globalization. In a 
1981 paper, Albert Hirschman acknowledged the demise of developmental economics in the title of his paper, 'The rise and decline of development economics.'

But classical developmentalism was not dead. In the following 30 years, the significant contributions to developmental economics were of an historical nature. I mention five notable books:

- Chalmers Johnson's 1981 book on Japan, MITI and the Japanese Miracle;

- Alice Amsden's 1989 book on South Korea, Asia's Next Giant;

- Robert Wade's 1990 book on Taiwan, Governing the Market;

- Ha-Joon Chang's 2002 book, Kicking Away the Ladder; and

- Eric Reinert's 2007 book, How Rich Countries got Rich... and Why Poor Countries Stay Poor (2007).

The first three books conveyed no new theory, but clearly showed the historical role played by industrial policy. They refrained from discussing the macroeconomic problems in Japan, South Korea, and Taiwan, because their assumption was that the macroeconomic prices (the profit rate, the wage rate, the exchange rate, the interest rate, and the inflation rate) were basically right in these countries. ${ }^{6}$ Indeed, in managing their macroeconomic policies these Asian countries were adamant about three things: fiscal responsibility (rejecting budget deficits except in a counter-cyclical way), exchange-rate responsibility (keeping the exchange rate competitive), and low interest rates. And we must consider that to keep the exchange rate competitive was something easier for them than for Latin American and African countries, because they don't dispose of the abundant and low-price natural resources that originate the Dutch disease.

The last two books demonstrated with historical facts that hegemony imperialism (imperialism by persuading or pressing developing countries to engage in currentaccount deficits) continues strong and represents a major obstacle to economic growth in so far as it presses developing countries to avoid using the policies and long-term institutions that they used when they were at the same stage of growth.

\section{SOCIAL-DEVELOPMENTALISM}

New developmentalism is the sum of the new and relatively consistent theories and ensuing policies on growth and progress, which, by its relative novelty in relation to other theories and by its internal consistency, may give rise to a new school of thought. In 2010, the approval of the '10 Theses on New Developmentalism' by a large number of economists of many nationalities, as well as the increasing consistency of the ideas being developed, point in this direction. ${ }^{7}$ Whereas the criterion on which really existing developmentalism is verified is the extent to which it is able to form a developmental class coalition and combine growth with social progress, new developmentalism will make sense if its concepts and models are helpful in three ways: in explaining the stability and growth as well as the crises and low growth of countries, in predicting economic behavior, and in proposing good policies.

6. 'Right' prices not because they're determined by the market, but because the average rate of profit combined with low interest rates are satisfying for business enterprises to invest, the exchange rate is competitive, wages consistent with the profit rate, and inflation low.

7. On the 10 Theses on New Developmentalism, see www.tenthesesonnewdevelopmentalism. org/. 
New developmentalism is, by design, democratic and progressive, because its proponents are critical of the inequality that characterizes capitalist societies, because they understand that economic development is only sustainable when wages grow in the long term, and because it is targeted at middle-income countries, which are already democratic or mature enough to be so, and, thus, the demands of their workers and their poor cannot be ignored.

Some critics would like a compromise between new developmentalism and socialdevelopmentalism, but this would require that social-developmentalism was also a new and competing theoretical framework - which is not the case (see Ferrari Filho and Fonseca 2015; Mollo and Amado 2015). Social-developmentalism ignored new developmentalism's models and policy proposals, but was not able to develop new ones. To be an alternative to new developmentalism, social-developmentalism should also have a body of new and relatively systematic theoretical knowledge, but it remained the prisoner of a version of Keynesianism and of classical developmentalism with a strong bias for immediate consumption, to which the economists who founded these two theoretical traditions, such as Keynes and Kaldor, or Nurkse and Prebisch, would probably not subscribe (see, for instance, Bastos 2012; Carneiro 2012).

Let us see which are the policies that distinguish social-developmentalism from new developmentalism. First, the defense of a wage-led strategy against an exportled or profit-led strategy. A wage-led strategy would solve the problem of insufficiency of demand, provided that the capitalists' marginal propensity to consumption was high as it usually is, and would reduce income inequality by increasing wages instead of making the exchange rate competitive, that is, floating around the industrial equilibrium. This involves a double mistake, whose formalized origin is the paper by Bhaduri and Marglin (1990). Reading the paper carefully reveals that it is practically a closed model, in so far as a wage-led strategy may only work when the country protects its domestic market with high tariffs; or, in other words, when it adopts the import substitution model of industrialization - something that makes sense to poor countries that are beginning their industrialization, but definitely does not make sense for middle-income countries to which new developmentalism applies. Second, it assumes that a competitive exchange rate is consistent with a less unequal distribution of income, which, as we will see in the next paragraph, is true in relation to the profits that must be satisfactory to motivate business enterprises to invest, and false in relation to the rentiers' revenues (the payment of interests, real-estate rents, and dividends), which, in relation to the exchange rate, vary in real terms in the same way wages vary.

Second, the claim that new developmentalism shows little concern for inequality makes no sense in so far as a theory is right or wrong, not conservative or progressive. As to policies proposed by new developmentalism, or, more specifically, by me, I understand that they are progressive is so far as I believe that the reduction of inequality is a major objective in capitalist societies that are inherently unequal and unjust. But this does not mean that the policies proposed should always express the short-term interests of the workers or of the poor. New developmentalism assumes that the exchange rate in developing countries is, 'normally,' overvalued in the long term, particularly in those that have the Dutch disease. It follows from this that the expected profit rate will usually be low, not sufficient to make business enterprises to invest, whereas real wages will be artificially high. Thus, it proposes policies that involve a once-andfor-all depreciation that is a condition for a satisfactory expected rate of profit - a rate of profit that motivates business enterprises to invest. Social-developmentalists view this policy that aims to make the business enterprises profitable or competitive as 'conservative.' In this way, they ignore that policymakers in a capitalist society 
have to obey the logic of capitalism - the logic of profit realization and capital accumulation. If growth depends on the investments of business enterprises, they should work for a compromise between business entrepreneurs and workers, between a satisfactory profit rate and wages increasing with productivity. Instead, social-developmentalists express a strong preference for high wages and immediate consumption - a preference that, in the medium term, is in the interest of rich countries, not of the workers and the poor of the developing countries. They assert that the exchange rate should be competitive, but, besides not having any concept of what is a competitive exchange rate, they don't want to pay the price - they don't want the short-term and modest fall in real wages that depreciation brings. And they often add that the depreciation will increase inequality, which is true just in relation to profits, but to increase them is the explicit objective of the depreciation. As to the other revenues, the depreciation is neutral: not only real wages but also the high salaries and bonuses of high technobureaucrats, and the real dividends, real-estate rents, and interests of rentier capitalists, will fall in real terms. The policies supported by new developmentalism that are effective in reducing inequality are not macroeconomic policies, but microeconomic ones: specifically the increase of the minimum wage and progressive taxes.

Third, new developmentalism wants the five macroeconomic prices to be correct, while this type of classical developmentalism gives preference to quantities against prices, and supposes that investments, for instance, show a low elasticity to the exchange rate and the expected profit rate, and a high elasticity to the increase in total wages and consumption. In doing that, it ignores the fact that economics is the science of markets and prices, where income effects are relevant, but prices remain the crucial coordinating tool of an economic system.

Fourth, the adoption of chronic budget deficits that increase the public debt-to-GDP ratio is another serious mistake, and a source of repeated failures on the part of heterodox policymakers. It is probably the worst virus suffered by some post-Keynesians and classical-developmentalists. Keynes abhorred such policies. Nevertheless they are often adopted in his name. In 1991, I and Fernando Dall'Acqua published a paper in the Journal of Post Keynesian Economics defending Keynes from this type of populism. True, the proponents of chronic budget deficits say that they only defend this kind of policy when there is insufficiency of demand, and that makes it counter-cyclical. Actually, they have such a loose concept of insufficiency of demand that every economic condition fits in it and wrongly legitimizes expansionary fiscal policy.

Thus, social-developmentalism lacks the statute of a theoretical system; it does not have the models of new developmentalism that I will summarize as follows: the tendency to the cyclical and chronic overvaluation of the exchange rate; the investment rate as a function of the exchange rate combined with the claim that besides demand business enterprises require access to it to invest; the model of the Dutch disease; the model of the substitution of foreign for domestic savings; etc. It also makes serious policy mistakes, which originate from its difficulty in understanding the logic of capitalist development - an often perverse logic, but from which the policymaker cannot escape. Take, for instance, the perverse logic of economic crises and the required adjustments. They reduce the wages of workers, while they preserve the interests, real-estate rents and dividends of rentiers. But they also preserve the profits - and this is good, because the objective of the adjustment is to restore the profit rate, upon which the resumption of investments depend.

Actually, the adoption of the social-developmental policies that I just criticized plus ignorance of the new models that new developmentalism has brought to the fore are the main reasons for the frequent failure of heterodox policies in developing countries. 
Take the recent case of Brazil. The Lula administration (2003-2010), which benefited from a commodity boom, profited from the opportunity to increase the minimum wage, thus reducing the inequality. But it made the major mistake of letting the exchange rate become dramatically overvalued: during the 8 years of his administration, it went from R $\$ 5.1$ per US dollar in the first month to just $\mathrm{R} \$ 1.90$ in the last one, December $2010 .^{8}$ In consequence, the large increase in the domestic market that the competent distributive policy and the commodity boom created was fully captured by imports. The Brazilian manufacturing industry, which began losing the foreign markets to other countries, also lost the domestic market to importers.

As to the loose concept of insufficiency of demand justifying large budget deficits, we have the last 2 years of the first Dilma administration (2013 and 2014) to examine. In the beginning of her administration, she courageously reduced the interest rate and devalued the real by around 20 percent, to $\mathrm{R} \$ 2.30$ per dollar. It was a necessary but insufficient devaluation, since the industrial equilibrium in Brazil in January 2015 should have been around $\mathrm{R} \$ 3.00$ per dollar. The economy, which was growing very slowly, didn't react, and manufacturing industry was in full crisis. At that moment, the government decided to increase expenditures to finance a very expensive industrial policy. But it didn't work, because an industrial policy is not a legitimate substitute for making the exchange rate competitive. Given that, inflation increased somewhat and the primary surplus, which should be about 2.5 percent of GDP, was zeroed out. The per capita growth rate resumed its quasi-stagnant average since 1980: less than 1 percent per year. ${ }^{9}$ In consequence, the government lost the confidence of the domestic and the international markets, and was forced into retreat in the first Dilma administration, by increasing the interest rate, and after re-election, by transferring the Finance Ministry to an orthodox economist. These were the consequences of Lula and Dilma's socialdevelopmentalism. Brazil is a country where heterodox economics remains relatively strong, and for some time we became mainstream in the policy sector (not in the academic sector: that is a closed bulwark). We ceased to be in the mainstream during the second Dilma administration, which represented a major defeat for us.

Summing up, given the insufficient expected rates of profit, the low investments, and the low growth rates - characteristics of a pseudo-developmentalism, not of a socialdevelopmentalism - the developmental class coalition aimed at by the Workers' Party's three administrations in the last 12 years failed to turn into reality. Instead of getting tangled in old populist practices and in ideas, developmentalists and postKeynesians must seek new ideas and new policies. Developing countries don't only need growth; they also need less economic inequality. But it is not by keeping the more strategic macroeconomic price - the national currency price or the exchange rate - overvalued that we will achieve this goal. By doing that, we are only abiding those who are interested in long-term overvalued currencies in developing countries: the rich countries and the local rentier capitalists. New developmentalism only makes sense in the framework of a developmental class coalition aligning the businesses, entrepreneurs, public bureaucracy and workers to fight the neoliberal class

8. The reais are in real terms and are referenced to December 2014; they consider the inflation in Brazil and the United States.

9. The Brazilian economy has been almost stagnant since 1981: between that year and 2014 , the average rate of per capita growth was 0.94 percent per annum. If we exclude an exceptionally negative period (the year 1980, when the country has stagnated due to the financial crisis of foreign debt) and also exclude the commodity boom (2004-2010), the rate is even lower: 0.78 percent per year. 
coalition made up of rentier capitalists and financiers. Given the tendency toward the cyclical and chronic overvaluation of the exchange rate, in the initial condition, the expected profit rate of manufacturing industry will be low, insufficient to make it worthwhile for the business enterprises to invest and innovate, and wages and all other revenues (interests, dividends, and rents on real estate) will be relatively high. This then requires a once-and-for-all depreciation, which will make the exchange rate competitive, and involves a fall in all revenues, not just of wages. Thus, what is really effective in reducing inequality is not the exchange-rate policy: it is the increase of the minimum wage, keeping the level of the interest rate low, and adopting a progressive income and inheritance tax system.

\section{SUMMING UP NEW DEVELOPMENTALISM}

Here is a summary of new developmentalism:

1. New developmentalism starts from the assumption that markets are excellent at coordinating the economy, but they don't assure the right microeconomic prices in the non-competitive sector of the economy, and they don't assure the right macroeconomic prices at all.

2. New developmentalism works with five macroeconomic prices: the profit rate, the exchange rate, the interest rate, the wage rate, and the inflation rate, and understands that they must be kept right.

3. 'Right' prices do not mean prices defined by full competition, but prices that make sense economically and politically: (a) the profit rate must be high enough to support investment by business; (b) the exchange rate must make business enterprises competitive; (c) the level of the interest rate should be as low as possible; (d) the wage rate should increase with productivity, and be consistent with a satisfactory profit rate; and (e) the inflation rate should be low.

4. The basic difference between rich and middle-income countries, besides the level of income, is the fact that while rich countries get indebted in their own money and are only subject to banking and financial crises, middle-income countries get indebted in foreign money (which they cannot either issue, or depreciate), being additionally subject to currency or balance-of-payment crises.

5. Economic development is a process of capital accumulation with the incorporation of technical progress that increases wages and standards of living in the long term; it supposes an increasingly well-educated population; it involves industrialization or, more precisely, increasing productive sophistication combined with the transference of labor from low to high income per capita industries.

6. Economic development is the main element of progress or human development, which also involves the increase in security, the increase of individual liberties, the reduction of inequalities, and the protection of the environment.

7. The method appropriate to understanding growth with price and financial stability is the historical-deductive method, which generalizes from the observation of empirical regularities, not from axioms on rational behavior.

\section{Growth and the investment rate}

8. As is well known, the growth rate depends on the investment rate, which depends on the difference between the expected rate of profit and the interest rate. The expected rate of profit depends on the existence of effective demand. 
9. But what is not usually known is that the expected profit rate depends on the level of the exchange rate, because the exchange is not just volatile around the equilibrium, but in developing countries, given the tendency to the cyclical and chronic overvaluation of the exchange rate, it is usually overvalued in the long term something that neoclassical and Keynesian macroeconomics don't acknowledge.

10. When the exchange rate is overvalued in the long term, the business enterprises that use state-of-the-art technology are disconnected from effective demand, as the average expected rate of profit falls and possibly turns negative, which leads them to reduce or stop investment.

11. When the investment rate is low, the rate of private savings will also be low, because, as Keynes showed, the latter depends on investment.

12. Private savings rate depends additionally on the national culture, and on the existence (or lack thereof) of a social security system, which is supposed to create savings on behalf of individuals.

13. Instead, given the budget deficit that keeps the public debt under control, public investment depends on public savings (taxes minus current expenditures) and on the profits of state-owned enterprises. ${ }^{10}$

\section{The determinants of the exchange rate}

14. The determinants of the exchange rate are its value and the supply and demand for foreign money.

15. The value of the exchange rate, or, more precisely, of foreign money, is the value that covers the cost plus a reasonable profit of the business enterprises that participate in foreign trade and ensure the equilibrium of the current account of the country.

16. The value of the exchange rate depends on the country's comparative unit labor cost (wage rate divided by productivity of the country compared with other countries).

17. The price of the exchange rate floats around its value according to the demand and supply of foreign money.

18. The supply and demand for foreign money (i) depends on the textbook determinants, particularly on the interest rate (which attracts capital when it increases) and on the purchase or selling of foreign reserves by the central bank; (ii) on the speculative capital flows; and (iii) on the three habitual populist policies that developing countries adopt: the policy of growth with current-account deficits ('foreign savings'), the policy of a high level of the basic interest (well above the international rate), and the use of an exchange rate anchor to control inflation.

\section{Dutch disease}

19. When a country faces the Dutch disease, there are two values and corresponding equilibriums for the exchange rate: the current equilibrium, which is the exchange rate that balances intertemporally the country's current account,

10. Public savings equal total revenue less consumption or current expenditures including interest on the public debt. 
and the industrial equilibrium, the exchange rate that makes competitive the business enterprises utilizing state-of-the-art technology.

20. The Dutch disease is the permanent overvaluation of the exchange rate caused by the fact that the country has abundant and cheap natural resources, which benefit from Ricardian rents, and so may be exported with a satisfactory profit at an exchange rate floating around the current equilibrium, which makes the non-commodity tradable industries non-competitive because they require that the exchange rate floats around the industrial equilibrium to be competitive.

21. Another way of defining the Dutch disease is to say that it is a long-term competitive disadvantage for the non-commodity tradable industries of a country that results from the fact that the technically competitive business enterprises are not economically competitive, because the former are profitable with a more appreciated exchange rate than that required by the latter, which benefit from Ricardian rents.

22. When the country does not face Dutch disease, the current and the industrial equilibriums are the same; in other words, there is only one value, around which floats the exchange rate price.

23. When there is Dutch disease, the exchange rate price floats around the current equilibrium, which is dominant because it is lower (more appreciated) than the industrial equilibrium.

24. The distance between the industrial and the current equilibrium indicates the severity of the Dutch disease.

25. The current equilibrium (i) depends on the international price of commodities, so when the price increases, the current equilibrium increases, making the Dutch disease less severe; (ii) depends on the export tax that the country uses to neutralize the Dutch disease; and (iii) depends, on the domestic side, on the tariffs on imports.

26. The industrial equilibrium depends on the value of the exchange rate relative to the manufacturing or non-commodity tradable industries, which depend on the comparative unit labor cost of the country in relation to its main trade competitors.

\section{The tendency toward overvaluation}

27. In developing countries there is a tendency toward the cyclical and chronic overvaluation of the exchange rate, which means that, contrary to Keynesian and neoclassical macroeconomics, the exchange rate tends to be overvalued in the long run. In Figure 1, the market exchange rate behaves accordingly, and we have two real (the current account and the industrial equilibrium) beside one false exchange-rate equilibrium (the foreign debt equilibrium).

28. There is a direct but non-linear relation between the exchange rate and the current account.

29. The current equilibrium is the value of the exchange rate that balances intertemporally the current account, and is the effective equilibrium around which the exchange rate floats; the industrial equilibrium is the value of the exchange rate that is required to make competitive the tradable business enterprises using the best technology available, and is the competitive equilibrium; the foreign debt equilibrium is the exchange rate that corresponds to a current-account deficit which keeps the foreign debt growing at the same rate as the GDP. 


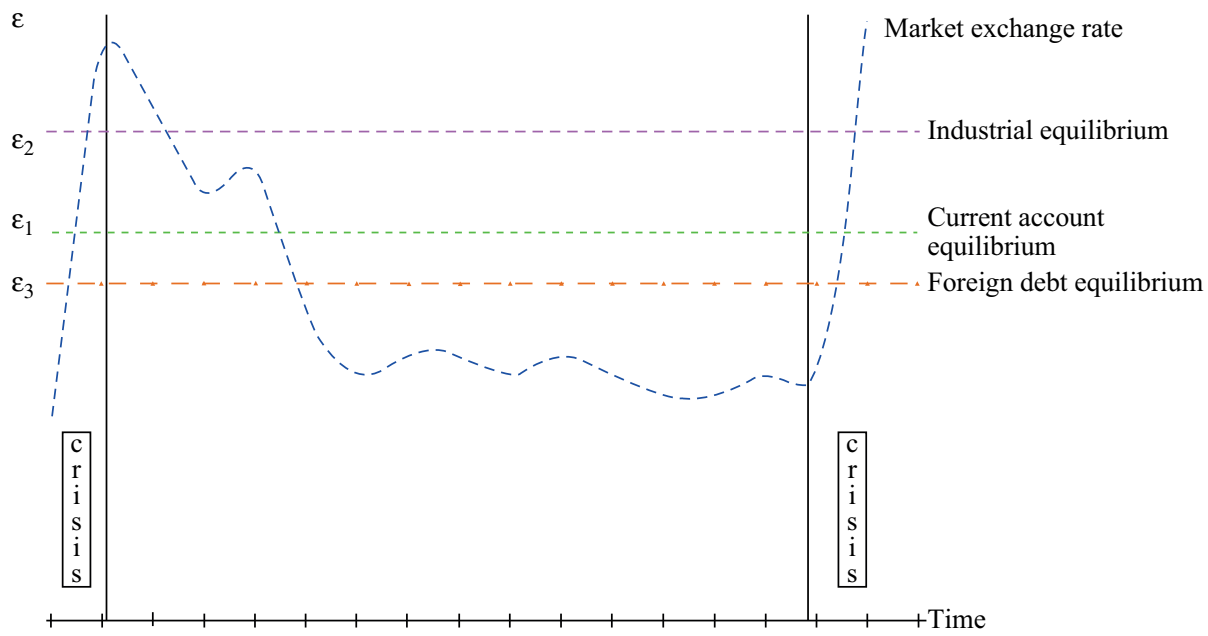

Figure 1 Tendency toward the cyclical and chronic overvaluation of the exchange rate

30. As a consequence of this tendency, besides investing too little, developing countries will go from one currency or balance-of-payments crisis to another, from one sudden stop to another sudden stop.

31. The tendency toward cyclical and chronic overvaluation of the exchange rate has a structural cause (the Dutch disease), and three habitual policy causes: (i) the growth cum current-account deficits (foreign savings) policy ignoring the high rate of substitution of foreign for domestic savings, complemented by the policy of keeping the interest rate at a level high enough (around which monetary policy is practiced) to attract capital; (ii) the adoption by the central bank of a high-level basic interest rate, well above the international rate, to control inflation and to attract capital flows; and (iii) the adoption of an exchange rate anchor to control inflation.

32. The Dutch disease is a long-term competitive overvaluation or disadvantage originating from the fact that the country benefits from Ricardian rents derived from abundant and cheap natural resources; such rents enable business enterprises to export commodities at a profit and at an exchange rate that floats around the current equilibrium, which is substantially more appreciated than the exchange rate required by other businesses enterprises producing tradable goods that use the best technology available in the world.

33. A non-neutralized Dutch disease means that, with the exception of the commodities that cause it, all existing and potential business enterprises producing tradable goods and services will be unable to invest and innovate because the expected profit rate will be small or negative. If the country neutralized the Dutch disease in the past, but later on ceases to do that (as was the case with Brazil), it will deindustrialize. ${ }^{11}$

11. Between 1967 and 1990 the 'confisco cambial' [exchange confiscation] was embodied in the country's trade policy: an average tariff on the import of manufactured goods of 45 percent and an average subsidy of the same 45 percent on the exports of manufactured goods implied a 
34. In most cases these often-adopted policies are forms of exchange rate populism because they lead the nation-state to spend irresponsibly more than it gets and to increase its foreign debt. And we have fiscal populism when the state spends irresponsibly more than it takes in and the public debt increases.

\section{Balance-of-payments crises}

35. The continuous appreciation caused by these four factors (the Dutch disease and the three habitual and, essentially, populist policies) will, first, involve a high rate of substitution of foreign for domestic savings. Second, it will increase the foreign debt and cause financial fragility, compelling the country to engage in the pathetic practice of 'confidence building' policy (to adopt policies not according to the interests of the country but according to the conditions demanded by the IMF and of the international financial system), and, third, it will trigger a balance-of-payments crisis, which completes the cycle.

36. If the Dutch disease is not duly neutralized, it will keep the exchange rate overvalued in the long-term. But as it only pushes the exchange rate from the industrial to the current equilibrium, it will not cause a balance-of-payments crisis. What pushes the exchange rate down to the current-account deficit is the three habitual and populist policies.

37. If the three habitual policies (growth cum current-account deficits and the exchange anchor) are not rejected, the exchange rate will sooner or later cross the foreign debt equilibrium. Then a balance-of-payments or a currency crisis will necessarily materialize.

38. The floating exchange rate regime does not prevent the financial crisis, because a bubble credit will keep the exchange rate overvalued for a long time, allowing the foreign debt to increase beyond a secure line.

\section{Policies}

39. New developmentalism does not have a special contribution in relation to monetary and fiscal policy. Monetary policy should make the interest rate vary around a reasonable level - just a little bit higher than the average level of the real international interest rate. ${ }^{12}$

40. Fiscal deficits are recommended only when there is a clear insufficiency of demand making the expenditures counter-cyclical. A loose definition of insufficiency of demand and the adoption of chronic budget deficits don't lead to growth and full employment; they are just an excuse for fiscal populism. To adopt a lax concept of insufficiency of demand and to propose chronic budget deficits is not Keynesian thinking, but vulgar Keynesianism.

41. As there is a monetary policy to determine the interest rate, an exchange-rate policy is essential to determine the exchange rate, which should not be thought

tax of 30 percent on the export of commodities. Policymakers adopted this policy without knowing that a large part of the tariff was not protectionism, but the necessary neutralization of the Dutch disease, which fluctuates around 20 percent in Brazil, becoming more or less serious as the price of commodities increases or decreases.

12. It should not be substantially higher because it should not be willing to attract foreign capital. 
to be just an endogenous variable and, so, reduced to monetary policy, that is, to a change of the interest rate.

42. Besides not being reduced to monetary policy, exchange-rate policy (i) should not be limited to the adoption or not of capital controls; (ii) involves the rejection of two habitual policies, namely the growth cum foreign indebtedness policy; and (iii) when there is Dutch disease, requires a once-and-for-all policy to neutralize it, namely an export tax on the commodities that originate the disease.

43. The policy of growth cum indebtedness or foreign savings is self-defeating: even if the current-account deficit is financed by direct foreign investments, the resulting capital inflow will appreciate the national currency, reduce the incentive for investment, and the usual outcome will be a high rate of substitution of foreign for domestic savings. This means that most of the foreign savings will finance consumption, not additional investment, even if the financing is made by direct investments.

44. This does not mean that the country should reject foreign direct investments. These investments are welcome if they bring technology or open new markets, and not because they finance current-account deficits - something that middleincome countries definitely should not have. Given that, foreign direct investments will increase reserves and finance foreign direct investments, as does China and the fast-growing Asian countries.

45. The use of the exchange rate as a nominal anchor against inflation is a major policy mistake; inflation may be controlled in this way, but at an absurd cost. If inflation is not inertial, the way to control it is through fiscal and monetary policy, besides macroprudential policies. The fact that a temporary rise of the interest rate to control inflation attracts capital is true, but this effect will be small.

46. The growth cum foreign indebtedness policy and the policy of controlling inflation with the appreciation of the national currency involve exchange-rate populism, which artificially increases wages and lowers inflation. In doing so it facilitates the re-election of politicians, but at the country's expense.

47. It makes no sense to keep the exchange rate overvalued in the long term and justify the policy with the argument that the depreciation required to make the exchange rate competitive will cause real wage reduction; it will also cause the reduction of other revenues, and, so, will not have a truly distributive outcome, except in favoring the expected profit rate; but this is the objective of the devaluation: to ensure a satisfactory profit rate, which motivates business enterprises to invest.

48. The reduction of inequality should be achieved through both a minimum wage policy, which reduces wage and salary differentials, and the restoration of a progressive tax system.

49. The neutralization of the Dutch disease is carried out by the imposition of an export tax on the commodities equal to its severity (the difference between the industrial and the current equilibrium). This tax will increase the cost of the commodity, its exporters will reduce their supply at the existing exchange rate, and the market will take charge of depreciating it.

50. A second-best way of neutralizing the Dutch disease is a linear (equal for all goods) increase in import tariffs by adding to it an 'exchange-rate tariff': this will neutralize the Dutch disease in the domestic market, but will continue to block competent firms seeking to export. 
51. Although the twin deficits hypothesis does not hold when the exchange rate is either overvalued or undervalued, it holds when the exchange rate is competitive. Given that in the countries that neutralize the Dutch disease the exchange rate will be competitive and the current account will show a surplus, or, if not a fiscal surplus, then, for sure, a budget deficit consistent with a small and controlled public debt.

52. The cost involved in neutralizing the Dutch disease and, more broadly, in neutralizing the tendency to the cyclical and chronic overvaluation of the exchange rate is a temporary one and relatively small; it will amount to a rise of inflation and a reduction of all revenues in real terms (the wages and salaries, and the interest, the real-estate rents, and dividends), except the profits of the business enterprises - precisely what is required to increase the investment opportunities that an overvalued currency depresses.

53. The outcome of these policies will be an increase in the profit opportunities, an increase in the investment rate, and in the export rate of manufactured goods, and, last but not least, the achievement of a current-account surplus. This will, necessarily, derive from the neutralization of the Dutch disease - from the shift from the current equilibrium to the industrial equilibrium, which, by definition, corresponds to a current-account surplus.

54. Thus, new developmentalism claims, counterintuitively but logically, that middle-income countries do not need foreign capital to grow; they will grow faster if they present current-account surpluses most of the time.

\section{Development strategy}

55. A growth strategy may be wage-led, neutral, or export-led, depending on whether the openness coefficient of the country is falling, constant, or increasing.

56. New developmentalism rejects a wage-led strategy, because such a strategy supposes protectionist tariffs, which are legitimate for countries that are beginning their industrialization, but not for middle-income countries, which must compete in the international markets.

57. New developmentalism favors an export-led strategy after the once-and-for-all depreciation required to move the value of the national currency from the current to the industrial equilibrium has had its short-term effect, and up to the moment when low wages represent a competitive advantage in relation to rich countries. After that, the strategy should be neutral or balanced in so far as the openness coefficient achieves its appropriate level, given the size of the country as the main factor.

\section{Microeconomics and distribution}

58. Prices vary according to the demand and supply around the value of the good or service, which is defined by the social labor required. Or, more simply, defined as the cost plus reasonable profit involved in its production.

59. The allocation of factors in the competitive sector is made by the market through the tendency toward the equalization of the rates of profit, whereas in the non-competitive sector (particularly in infrastructure), planning or state coordination is required. 
60. Industrial policy is part of the competitive game among nations, but it should be adopted strategically, as an addition to the right macroeconomic prices, particularly the profit and the exchange rate, never as a substitute.

61. The once-and-for-all depreciation of the exchange rate required to make the shift from the current to the industrial equilibrium implies an increase in the profit rate and a reduction of all revenues (wages, salaries, interest, dividend, and rent revenues); this is necessary to make the competent business enterprises competitive and assure full employment.

62. Minimum wage policy, a progressive tax structure and a low level of interest rates - not an overvalued currency - are the three legitimate and indispensable means to reduce economic inequality, which is inherent in capitalism.

63. The protection of the environment and a reasonable growth rate require a permanent compromise and a persistent search of win-win solutions.

\section{Political economy}

64. Capitalism is either market- and state-coordinated, or almost exclusively market-coordinated; in the first case the state will be developmental, in the second, economically liberal.

65. The first historical form of capitalism in each country - the one where the formation of the nation-state and the industrial revolution occurs - is always developmental and authoritarian. Considering only the countries that first industrialize, the first historical form of developmentalism was characterized by a mercantilist class coalition. Considering the latecomer or developing countries, the class coalitions had as models the Meiji Restoration and the Bismarckian class coalitions.

66. Economic liberalism was just a nineteenth-century attempt, never fulfilled, to make the coordination of capitalist economies depend only on self-regulated markets.

67. It was followed by a second developmentalism: the Fordist or social-democratic developmentalism. Neoliberal capitalism was a second and short-lived attempt to go back to the past.

68. A developmental class coalition associates business entrepreneurs, the public bureaucracy and the workers, whereas a liberal class coalition associates rentier capitalists, the financiers who manage the wealth of the former and the foreign interests.

69. Developmentalism was historically authoritarian and conservative. It only became democratic and progressive with social democracy or Fordism in the New Deal and the Golden Years of Capitalism.

70. New developmentalism, which focuses on middle-income countries that are supposed to be democracies, searches to be a progressive alternative not only to neoliberalism, but also to conservative developmentalism. In democratic middle-income countries, developmentalism is consistent with social democracy, not with socialist policies that underestimate the fact that a satisfactory profit rate is a condition for capitalist growth.

\section{CONCLUSION}

The 2008 global financial crisis represented a major setback for economic liberalism or neoliberalism; not for conservatism, which remains strong. The real option that not 
only middle-income countries but also rich countries face is not to choose either neoliberalism or developmentalism, but either conservative or progressive developmentalism. New developmentalism is an attempt to offer new ideas for developing countries, mainly middle-income countries, but should be ignored by rich countries. In economics new theories are very infrequent, almost inexistent. Nevertheless, I believe that most of these ideas are new or relatively new, and, besides being critical of neoclassical economics, are critical of both classical developmentalism and Keynesian Macroeconomics. For that reason, the followers of these schools of thought will be resistant to it. This is part of the eternal game of ideas and interests. Economists who remain attached to classical developmentalism will argue that this strategy is export-led, which is meaningless; they will say that only workers will lose, which is false. Vulgar Keynesians will argue that I am rejecting effective demand and only think in price terms, but economists who don't view prices as the core of their science are not real economists. As to liberal mainstream economists, they will probably ignore these new models because their theories are based on the hypothetic-deductive method; because, against all evidence, they reject an active role for the state and believe in self-regulated markets; and, above all, because they don't have sympathy for theories, like my model of the Dutch disease, which, when not neutralized, represents a major competitive disadvantage to the countries that suffer it, and when neutralized lead the country to display current-account surpluses. An outcome like this is not seen with sympathy by rich countries and their economists, because the basic legitimization of the investments of their multinational enterprises is the supposed 'need' or 'benefit' that developing countries would have for receiving their capital - a need or benefit that proves false when the outcome of the neutralization of the Dutch disease is necessarily a current-account surplus.

A way of summarizing developmental microeconomics is to say that it rejects the existence of self-regulating markets, but views markets as an irreplaceable institution to coordinate the competitive sector of the economy, whereas a way of summarizing developmental macroeconomics is to say that it is based on the right or balanced macroeconomic prices, particularly on a competitive exchange rate that makes economically competitive the business enterprises that are technologically competitive. The "heterodox' ideas that economics should not deal with equilibrium, and that growth and stability may be achieved without costs, make as little sense as does the 'orthodox' assumption that meaningful theory can be built based on the axiom that economic agents are rational and markets self-regulated.

New developmentalism is a project, a work in progress. Its contribution to macroeconomics and particularly to the theory of the exchange rate is already reasonably defined. The same cannot be said about its contribution to microeconomics, but the distinction of a competitive and a non-competitive sector in capitalist economies will play a major role in it. As to the political economy of new developmentalism, the theories on the crucial change that represents the capitalist revolution for each country, on the competition between nation-states in globalization, on the nature of developmental state, on economic nationalism, and on class coalitions, are its building blocks.

Returning to the beginning, new developmentalism is not a form of capitalism, but a theoretical framework. In a previous article (Bresser-Pereira 2016), I tried to portray it as something really existing, but I was mistaken. New developmentalism's predecessor is classical developmentalism, and it is associated with the post-Keynesian and French regulation schools of thought. New developmentalism includes a methodological critique of neoclassical economics, which adopts a hypothetic-deductive method, which is inconsistent with a substantive social science like economics (Bresser-Pereira 
2009a). Instead, new developmentalism's models are not inferred from a supposed rational agent, but from the regularities and tendencies that can be observed in the economic systems. The hypothetical-deductive method is properly adopted by the methodological sciences like mathematics, statistics, econometrics, and economic decision-making theory, whereas the empirical deductive method or the historical deductive method are appropriate to the substantive sciences, that is, the natural and the social sciences.

The new developmentalism project is a broad system of economic, political and social theories and policies that aim to understand how developing countries grow and the challenges they face. It will become influential only when a large number of economists and political scientists contribute to it. This is already taking place principally in Brazil, ${ }^{13}$ but there are also non-Brazilian economists associated with new developmentalism, particularly the ones who originally subscribed to the 10 Theses on New Developmentalism, who have shown a definite interest in the new ideas and models. ${ }^{14}$ Will new developmentalism bring enough people together and constitute a new Latin American school of thought, as the French Regulation School does? That is difficult to predict. It depends, essentially, on the consistency and truth of the theory's main ideas. When Robert Boyer, from the Regulation School, wrote the preface to the French edition of Globalization and Competition (2009), he said that a new school of thought was in the making. I was surprised at that moment, but now it may well be that he was right.

Many developing countries adopt a developmental approach because they reserve an important economic role to the state, but few countries adopt the right new-developmental policies that would assure their growth with financial stability. That failure is due to the fact that the capability of their states is poor, that the demands of the population for immediate consumption is high, and that their economists are often incompetent and as populist as are their politicians. New developmentalism is an effort to offer competent policies to these countries, particularly the middle-income countries. It is by design and by necessity a 'social' developmentalism, which looks to combine growth with a reduction of inequality. It is by design social, because its followers know well that, if capitalism is left free, it will be essentially unfair to the poor; it is by necessity social, because in democratic countries the poor are strong enough to demand and obtain the provision by the state of large and universal social services.

A final caveat. The adoption of new developmentalism is no guarantee of success. Comparing new developmental policymaking with liberal policymaking, the latter is an inferior choice because (i) it will tend toward financial instability, in so far as neoclassical economists believe that the private sector is market-coordinated and is always in equilibrium, which is false; (ii) it will be characterized by low growth, in so far as major market failures, beginning with the Dutch disease and the tendency to the

13. Among Brazilian economists, I cite Yoshiaki Nakano, José Luis Oreiro, Nelson Marconi, Paulo Gala, Lauro Gonzales, Carmen A. Varela, Eliane Araújo, André Nassif, Carmen Feijó, and Pedro Rossi, who were my co-authors in texts developing or applying the new ideas. I cite also contributions by Francisco Eduardo Pires de Souza, Luiz Fernando de Paula, Vera Cepeda, Marcus Ianoni, Ricardo Bielschowsky, Lauro Mattei, Marco Flávio da Cunha Resende, and Gilberto de Assis Libanio, as well as by those who compared new developmentalism with social-developmentalism: Maria de Lourdes Rollemberg Mollo, Adriana Amado, Pedro Cezar Dutra Fonseca, and Fernando Ferrari.

14. I cite Robert Boyer, Jan Kregel, Gabriel Palma, Ha-Joon Chang, Roberto Frenkel, José Antonio Ocampo, Jan Priewe, Philippe Faucher, Arturo Guillén, Robert Guttmann, Robert Blecker, Pierre Salama, Jaime Marques-Pereira, and Martin Rapetti. 
overvaluation of the exchange rate, are not neutralized; and (iii) it will lead to increased income inequality, given the commitment of their policymakers with the rentier class coalition. But developmental policymaking requires more technical competence than liberal policymaking, because it is more proactive. Incompetent liberal policymakers often engage in excessive fiscal austerity and exchange-rate irresponsibility, whereas incompetent developmental policymakers, besides showing exchange rate lack of responsibility, often incur fiscal irresponsibility, because they succumb to vulgar Keynesianism, which sees an increase in state expenditures as the solution to all problems. Note that the two mistakes are symmetrical. However, these orthodox recurrent mistakes lead the economy to unemployment, low growth, and recurrent financial crises, whereas the heterodox recurrent mistakes lead the economy, additionally, to fiscal crisis and inflation. This is more risky for the politicians in power, and is the main reason why developmental politicians often call on orthodox economists to run their finance ministries, leaving other ministries, like economic planning, industrial development, education, and health-care, to the heterodox economists. This is embarrassing to the latter, and should be something for us to think about. We will not be able to persuade the rentiers and financiers, but we should be able to persuade the industrialists and the progressive politicians, who are sympathetic to developmentalism, that our theory and our policies are superior.

\section{REFERENCES}

Amsden, Alice H. (1989), Asia's Next Giant, New York: Oxford University Press.

Bastos, Pedro Paulo Zahluth (2012), 'A economia política do novo-desenvolvimentismo e do social desenvolvimentismo,' Economia e Sociedade, special issue, 21, 779-810.

Bhaduri, Amit and Stephen Marglin (1990), 'Unemployment and the real wages: the economic basis for contesting political ideologies,' Cambridge Journal of Economics, 14(4), 375-393.

Boyer, Robert (2009), 'Preface,' in Luiz Carlos Bresser-Pereira, Mondialisation et Compétition, Paris: La Découverte, pp. 7-15.

Bresser-Pereira, Luiz Carlos (2009a), 'The two methods and the hard core of economics,' Journal of Post Keynesian Economics, 31(3), 493-522.

Bresser-Pereira, Luiz Carlos (2009b), Developing Brazil: Overcoming the Failure of the Washington Consensus, Boulder, CO: Lynne Rienner.

Bresser-Pereira, Luiz Carlos (2010), Globalization and Competition, Cambridge, UK: Cambridge University Press.

Bresser-Pereira, Luiz Carlos (2012), 'Democracy and capitalist revolution,' Économie Appliquée, 65(4), 111-139.

Bresser-Pereira, Luiz Carlos (2016), 'The new developmentalism as a Weberian ideal type,' in Mario Damill, Martín Rapetti, and Guillermo Rozenwurcel (eds), Macroeconomics and Development: Roberto Frenkel and the Economics of Latin America, New York: Columbia University Press, pp. 373-383.

Bresser-Pereira, Luiz Carlos (2014), 'The access to demand,' in Dimitri B. Papadimitriou (ed.), Contributions to Economic Theory, Policy, Development and Finance, London: Palgrave Macmillan, pp. 196-206.

Bresser-Pereira, Luiz Carlos (2015), 'After the demise of neoliberalism but not of conservatism, a third developmentalism?', discussion paper, São Paulo School of Economics of Getulio Vargas Foundation, available at www.bresserpereira.org.br.

Bresser-Pereira, Luiz Carlos and Fernando Dall' Acqua (1991), 'Economic populism versus Keynes: reinterpreting budget deficit in Latin America,' Journal of Post Keynesian Economics, 14(1), 29-38.

Bresser-Pereira, Luiz Carlos, José Luis Oreiro and Nelson Marconi (2014), Developmental Macroeconomics, London: Routledge. 
Carneiro, Ricardo de Medeiros (2012), 'Velhos e novos desenvolvimentismos,' Economia e Sociedade, special issue, 21, 749-778.

Chang, Ha-Joon (2002), Kicking Away the Ladder, London: Anthem Press.

Corden, W.M. and J.P. Neary (1982), 'Booming sector and de-industrialization in a small open economy,' Economic Journal, 92(368), 825-848.

Ferrari Filho, Fernando and Pedro Cezar Dutra Fonseca (2015), 'Which developmentalism? A Keynesian-institutionalist proposal,' Review of Keynesian Economics, 3(1), 90-107.

Hirschman, Albert O. (1981), 'The rise and decline of development economics,' in Albert O. Hirschman, Essays in Trespassing, New York: Cambridge University Press, pp. 1-24.

Johnson, Chalmers (1982), MITI and the Japanese Miracle, Redwood City, CA: Stanford University Press.

Mercadante, Aloízio (2010), As Bases do Novo Desenvolvimentismo no Brasil, Tese de Doutoramento, Universidade Estadual de Campinas, Instituto de Economia, novembro.

Mollo, Maria de Lourdes Rollemberg and Adriana Amado (2015), 'The "developmentalism" debate in Brazil: some economic and political issues,' Review of Keynesian Economics, 3(1), 77-89.

Reinert, Erik S. (2007), How Rich Countries got Rich... and Why Poor Countries Stay Poor, New York: Carroll \& Craf.

Wade, Robert (1990), Governing the Market, Princeton, NJ: Princeton University Press. 